\title{
The influence of atmospheric circulation on the type of precipitation (Kraków, southern Poland)
}

\author{
Robert Twardosz • Tadeusz Niedźwiedź • \\ Ewa Lupikasza
}

Received: 25 February 2010 / Accepted: 6 September 2010 /Published online: 21 September 2010

(C) The Author(s) 2010. This article is published with open access at Springerlink.com

\begin{abstract}
The paper discusses the impact of atmospheric circulation on the occurrence of various types of precipitation. A 146-year-long precipitation record from Kraków spanning the period 1863-2008 was used alongside a calendar prepared by Niedźwiedź (1981, 2009) describing circulation types covering the period 1873-2008 and air masses and atmospheric fronts covering the period 1951-2008 in southern Poland. The influence of atmospheric circulation on precipitation was measured using the frequency, conditional probability and average daily totals of precipitation. Circulation types, air masses and atmospheric fronts exerted influences on precipitation as a result of the seasonal variations of the thermal and moisture properties of air masses. The impact is best expressed by circulation types as these combine the aspect of cyclonicity/anticyclonicity with that of the direction of air advection, the two elements which determine the physical properties of the air. On average, liquid precipitation prevailed in all circulation types, except the Ea type in which snowfall dominated over
\end{abstract}

\footnotetext{
R. Twardosz $(\bowtie)$

Department of Climatology, Jagiellonian University,

ul. Gronostajowa 7,

30-387 Kraków, Poland

e-mail: r.twardosz@uj.edu.pl

T. Niedźwiedź $\cdot$ E. Łupikasza

Department of Climatology, University of Silesia,

Będzinska 60,

41-200 Sosnowiec, Poland

T. Niedźwiedź

e-mail: tadeusz.niedzwiedz@us.edu.pl

E. Łupikasza

e-mail: ewa.lupikasza@us.edu.pl
}

liquid precipitation. Depending on the season, one of the three types of circulation, $\mathrm{Wa}, \mathrm{Wc}$ and $\mathrm{Bc}$, were shown to coincide with the greatest amount of liquid and thunderstorm precipitation. There was no single dominant circulation type for mixed precipitation or snowfall. In summer, the circulation types $\mathrm{Nc}, \mathrm{NEc}, \mathrm{Cc}$ and $\mathrm{Bc}$ were the most favourable to liquid and thunderstorm precipitation in terms of both probability and totals. In winter, snowfall was the most favoured by the Ec type. Frontal precipitation was twice as likely to occur as air mass precipitation, with the exception of snowfall which was predominantly an air mass type of precipitation in terms of probability, but its greatest totals were recorded on atmospheric fronts.

\section{Introduction}

The most widely available type of data on precipitation is the daily total. This is not surprising considering that the majority of weather stations are limited in their precipitation measurements to just recording the amount of water collected in a unit of time, which typically is a 24-h day.

Other measures used to characterise precipitation, such as frequency of occurrence, intensity or type, are less frequently used.

Precipitation types are rarely the subject of climatological research (Changnon 2001; Dai 2001; Przybylak 2002; Ye 2008). Indeed, coding of precipitation types requires a great deal of precise information about weather phenomena ('ww'), which is only available from round-the-clock visual observation. For this reason, few weather stations offer secular data about precipitation types. Time span variability of precipitation is still poorly understood. Studies into precipitation types in Central Europe, including those of 
Fig. 1 Krakow on a map of Poland

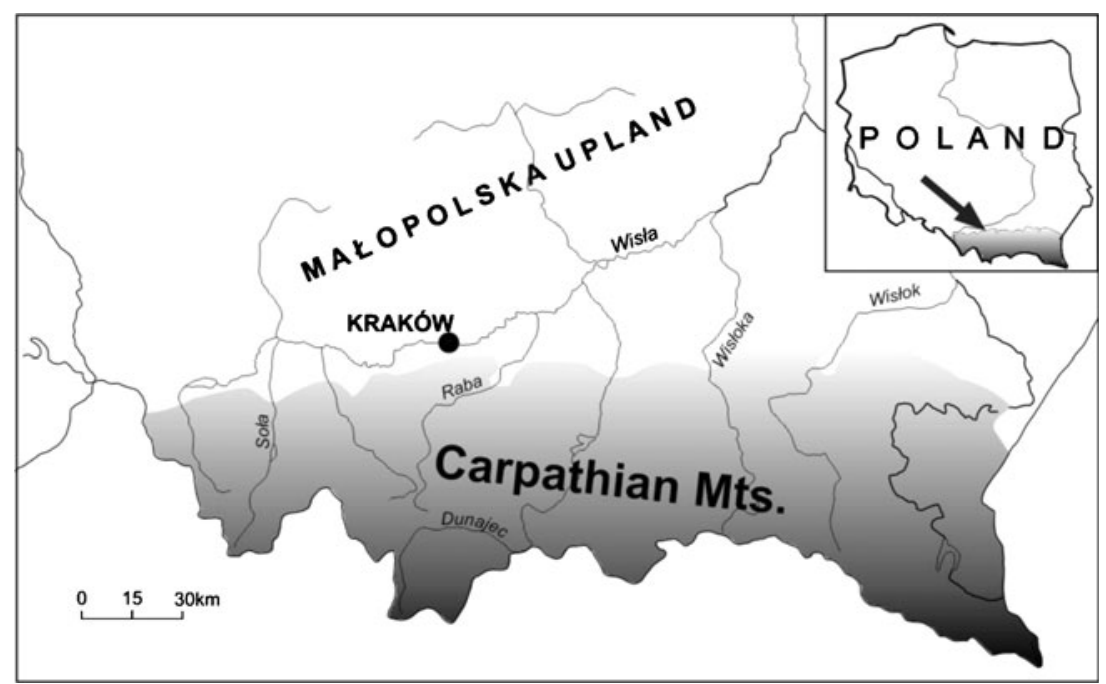

Spreitzhofer (1999a, 2000) and Twardosz (2002-2003), 2003a), focused primarily on snowfall variability.

Atmospheric circulation is widely agreed to play a key role among many factors shaping the frequency and amount of precipitation. In the study of the causes of precipitation variability, the impact of atmospheric circulation is assessed using either macroscale indicators, such as the NAO (e.g. Hurrell 1996; Wibig 2001) and regional indicators (e.g. Niedźwiedź et al. 2009), or simply circulation types as such (Twardosz and Niedźwiedź 2001; Twardosz 2009). Whilst little research is available on the influence of circulation on specific precipitation types, these are exactly the kind of pressure patterns that seem important to investigate in the temperate zone where frequent changes of pressure systems control the exchange of air masses. Some public research in this area targeted snowfall using either the NAO indicator (e.g. Hurrell 1996; Hartley and Keables 1998; Hurrell and Dickson 2004; Durkee et al. 2007; Falarz 2007), the El Niño-Southern Oscillation (Kunkel and Angel 1999) or circulation types (Twardosz 2002-2003, 2003b). Other studies sought to establish relationships between snowfall and synoptic patterns in southeastern USA (McGinnis 2000) or between intensive snowfall and synoptic patterns in Central Europe (Spreitzhofer 1999b; Twardosz 2003b Bednorz 2008) and in western USA (Younkin 1968).

The objective of this study was to determine the impact of atmospheric circulation types, types of air masses and of atmospheric fronts on the frequency of occurrence of various types of precipitation in the southern Polish city of Kraków (Fig. 1). The area belongs to a transitional portion of the temperate climate zone separating the continental climate from the maritime climate. Often, this is where air masses with different thermal and moisture properties clash, producing a high degree of weather fluctuation and precipitation types.

In this part of Central Europe, Kraków has the only uniform and unbroken record of quantitative and qualitative precipitation observations of more than 150 years. Since the establishment of the local weather station in 1792, observations have been performed by skilled observers as meteorologists took over from astronomers
Table 1 Codes of precipitation types with concurrent phenomena (Niedźwiedź 2007, Codes of precipitation types with concurrent phenomena, personal communication)

\begin{tabular}{ll}
\hline Code no. & Phenomena characteristic \\
\hline 0 & Day without precipitation and thunderstorm \\
1 & Rain, drizzle (liquid precipitation) \\
2 & Rain with snow (mixed precipitation) \\
3 & Snow-different forms (also diamond dust, snow crystals, snow grains, ice pellets) \\
4 & No precipitation, water in rain gauge from deposits or fog with rime \\
5 & Hail without thunderstorm \\
6 & Distant thunderstorm, no precipitation at the station \\
7 & Thunderstorm with snow or mixed precipitation \\
8 & Thunderstorm with rain (without snow and hail) \\
9 & Thunderstorm with hail (hailstorm) \\
\hline
\end{tabular}


Fig. 2 Examples of defined anticyclonic (left) and cyclonic (right) circulation types on synoptic maps of Europe (Niedźwiedź 1981)
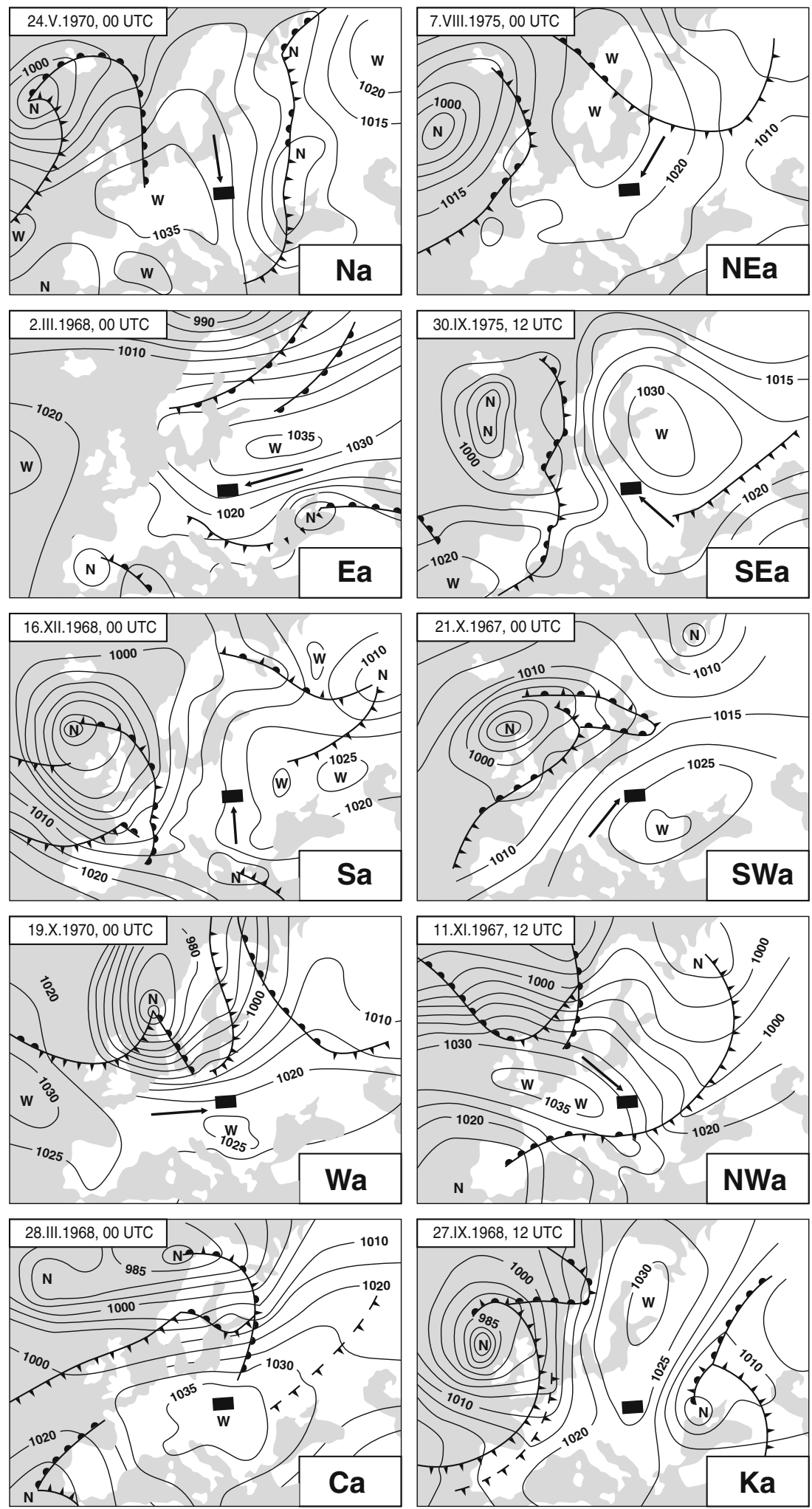

in the 1950s (Twardosz and Cebulska 2010). Additionally Kraków's precipitation fluctuations correlate well with precipitation recorded elsewhere in both the eastern and western parts of Central Europe (Niedźwiedź et al. 2009).
For these reasons, it can be assumed that results from Kraków are representative of an area wider than the city itself. Kraków receives approximately $670 \mathrm{~mm}$ of precipitation every year, which is approx. $90 \mathrm{~mm}$ more than the 
Fig. 2 (continued)
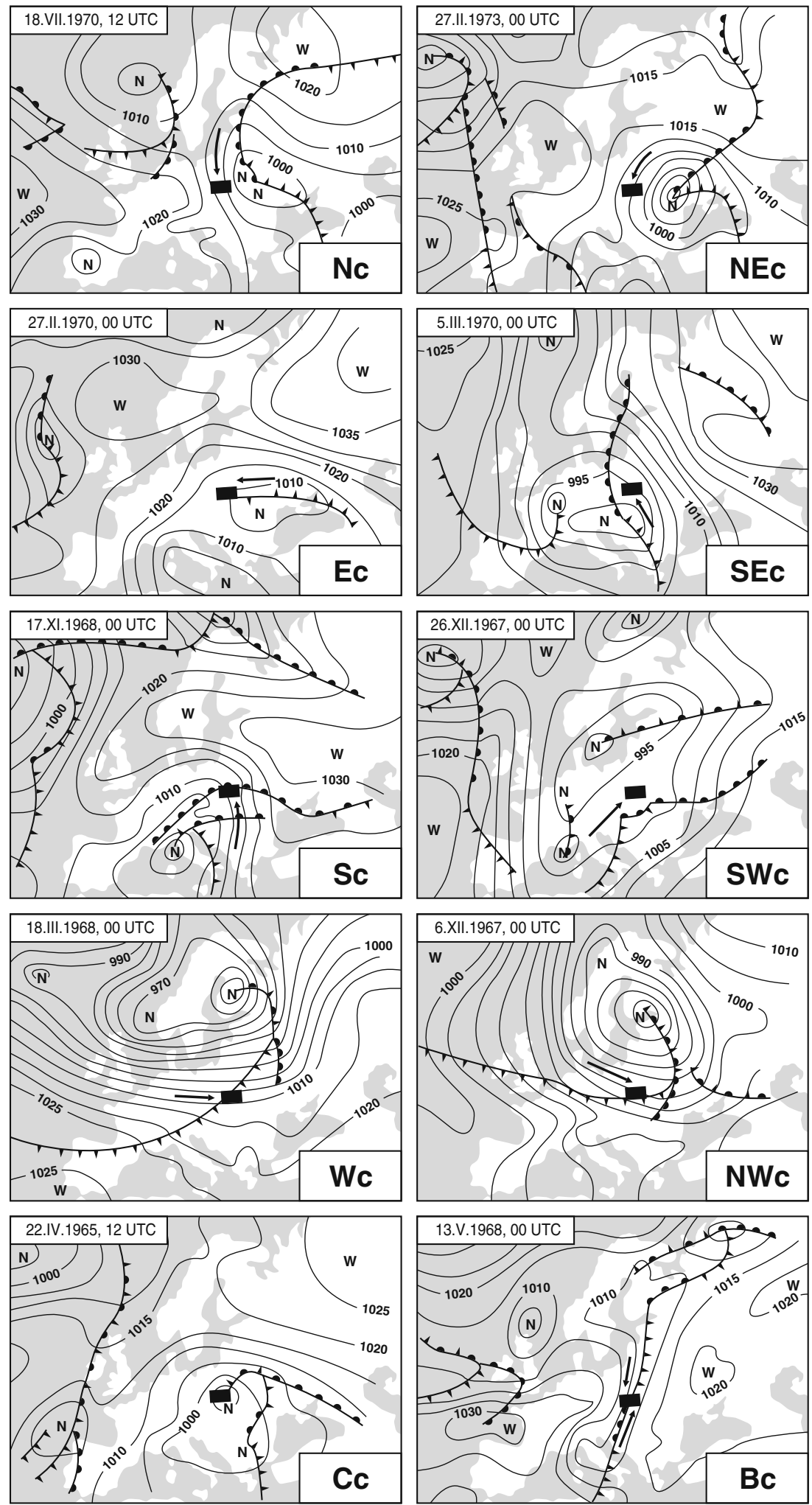

area-averaged precipitation total in Poland. This effect is caused by an influence of the local land relief and by atmospheric circulation (Twardosz 2007). Whilst Kraków is located in a concave terrain form, between the
Carpathian Mountains in the south and the Malopolska Upland in the north, the higher precipitation is more a result of an orographic effect than of an urban effect (Twardosz 2010a). 
Table 2 Frequency (\%) of precipitation types in Kraków (1863-2008) as a percentage of the total days with precipitation $(p \geq 0.1 \mathrm{~mm})$

\begin{tabular}{lcrrrr}
\hline Code no. & Spring & Summer & Autumn & Winter & Year \\
\hline 1 & 60.9 & 65.4 & 75.8 & 31.4 & 58.1 \\
2 & 11.7 & 0.1 & 7.2 & 19.4 & 9.6 \\
3 & 13.3 & 0.0 & 7.2 & 46.4 & 17.0 \\
4 & 0.4 & 0.3 & 5.5 & 2.0 & 2.0 \\
5 & 0.8 & 0.3 & 0.4 & 0.0 & 0.3 \\
7 & 0.4 & 0.0 & 0.1 & 0.5 & 0.2 \\
8 & 11.2 & 31.9 & 3.5 & 0.3 & 11.7 \\
9 & 1.4 & 2.0 & 0.3 & 0.0 & 0.9 \\
Total $1-9$ & 100 & 100 & 100 & 100 & 100 \\
Thunderstorm precipitation $7+8+9$ & 13.0 & 33.9 & 3.9 & 0.8 & 12.9 \\
Snow 2+3+7 & 25.4 & 0.1 & 14.5 & 66.3 & 26.8 \\
Days with $p \geq 0.1$ mm & 42.8 & 43.9 & 42.6 & 45.0 & 174.2 \\
Days with $p=0$ or trace & 49.2 & 48.1 & 48.4 & 45.3 & 191.0 \\
\hline
\end{tabular}

\section{Data}

\subsection{Precipitation data}

The study is based on a secular record of long-term precipitation from Kraków spanning 1863-2008. This data series goes back even further as the beginning of instrumental measurements of precipitation date back to August 1849 and has continued ever since. The choice of 1863 as the start of the period selected for the purposes of this study was dictated by the fact that only from that year onwards did the original 24$\mathrm{h}$ precipitation totals lend themselves to unification with the 24-h precipitation day that is currently applicable in the Polish weather service, i.e. from 0600 to 0600 hours UTC (Twardosz 1997). Between 1849 and 1863, daily precipitation totals were measured at 2100 hours local time (about 1940 hours UTC). Homogeneity of the measurement data was facilitated by extensive metadata available from the station's archive. Indeed, visual observations of atmospheric phenomena accompanying precipitation, especially in terms of their form and type, are very important for the study of precipitation.

The raw data used here included daily precipitation totals and details about their form and type contained in descriptions of daily atmospheric phenomena. The World Meteorological Organisation (WMO 1998) differentiates between as many as 99 'ww' codes defined by phenomena occurring during and prior to the weather observation ('W1' and 'W2'). Precipitation details are included in a majority of meteorological codes. With such a large range of phenomena, it is inevitable that some of them occur very seldom or not at all in the medium latitudes. For this reason, the study follows a code of types developed by Niedźwiedź (2007, Codes of precipitation types with concurrent phenomena, personal communication; Table 1), previously used by the author in Twardosz (2007), rather than using the WMO code. Only one code from the range of nine was attached per daily precipitation total (including a dry day with a thunderstorm). The codes indicate the form of the precipitation (liquid, solid or mixed) and thunderstorm phenomena. Thunderstorm precipitation was classified as such where accompanied by acoustic phenomena (thunder) and electrical phenomena. Thunderstorms are denoted by codes ranging from 6 to 9 . Codes 7 to 9 reflect thunderstorms accompanied by various precipitation types (rain, snow or hail), whilst the no. 6 denotes a thunder heard, but without any precipitation at the station. The combined total of codes 6 to 9 produces the overall number of days with a thunderstorm.

\subsection{The classification scheme for circulation types, air} masses and fronts

In synoptic and climatologic research, the right choice of classification of atmospheric circulation types plays a significant role. In studies of climatic elements seen at a local scale, it is mesoscale classification compiled for small areas that is the most useful. In this study, the authors chose a Calendar of Synoptic Situations by Niedźwiedź $(1981,2009)$ which is popular and widely used by Polish climatologists. This subjective classification includes circulation types that had occurred from September 1873 onwards and types of air masses and atmospheric fronts that occurred from January 1951. In putting this together, T. Niedźwiedź used the surface synoptic maps of Europe at 0000 and 1200 hours UTC. The Niedźwiedź classification of circulation types is similar to that of Lamb (1972) popular in the UK (Barry and Carleton 2001). The most important components of the circulation types are advection direction and cyclonicity or anticyclonicity of flow. In total, Niedźwiedź defined 21 types of atmospheric circulation, including 16 advection types, and coded them with the advection sector name and either the letter "a" for anticyclonic systems ( $\mathrm{Na}, \mathrm{NEa}, \mathrm{Ea}, \mathrm{SEa}, \mathrm{Sa}$, SWa, Wa and NWa) or "c" for cyclonic systems (Nc, NEc, 
Table 3 Proportion (\%) of precipitation totals broken down by types in seasonal and annual totals (Pmm) in Kraków (1863-2008)

\begin{tabular}{lrrrrr}
\hline Code no. & Spring & Summer & Autumn & Winter & Year \\
\hline 1 & 56.4 & 50.7 & 76.4 & 31.9 & 55.0 \\
2 & 13.3 & 0.0 & 9.2 & 29.5 & 9.4 \\
3 & 6.3 & 0.0 & 4.6 & 36.8 & 7.8 \\
4 & 0.0 & 0.0 & 0.3 & 0.2 & 0.1 \\
5 & 0.6 & 0.2 & 0.3 & 0.0 & 0.3 \\
7 & 0.5 & 0.0 & 0.1 & 0.9 & 0.3 \\
8 & 18.2 & 43.5 & 8.1 & 0.6 & 23.6 \\
9 & 4.6 & 5.6 & 1.2 & 0.0 & 3.6 \\
Total 1-9 & 100.0 & 100.0 & 100.0 & 100.0 & 100.0 \\
Thunderstorm precipitation $7+8+9$ & 23.3 & 49.1 & 9.4 & 1.5 & 27.5 \\
Snow 2+3+7 & 20.1 & 0.0 & 13.9 & 67.2 & 17.5 \\
P mm & 153.7 & 274.4 & 150.5 & 98.1 & 676.7 \\
\hline
\end{tabular}

Ec, SEc, Sc, SWc, Wc and NWc). The remaining five types are either advection-free or with varied advection directions:

- $\mathrm{Ca}-$ central anticyclonic situation, no advection, centre of high pressure;

- $\mathrm{Ka}$ - anticyclonic wedge, sometimes a few non-definite centres or an unconstrained area of higher pressure, an axis of a high pressure ridge;

Fig. 3 Statistics of daily totals of precipitation by seasons in Kraków (1863-2008)
- $\mathrm{Cc}$ - central cyclonic situation, centre of low pressure;

- $\mathrm{Bc}$-cyclonic trough or unconstrained area of low pressure or the axis of the low-pressure trough, with various advection directions and systems of fronts separating different air masses;

- $\mathrm{X}$-unclassified situations.

Examples of defined circulation types on synoptic maps of Europe are presented in Fig. 2.
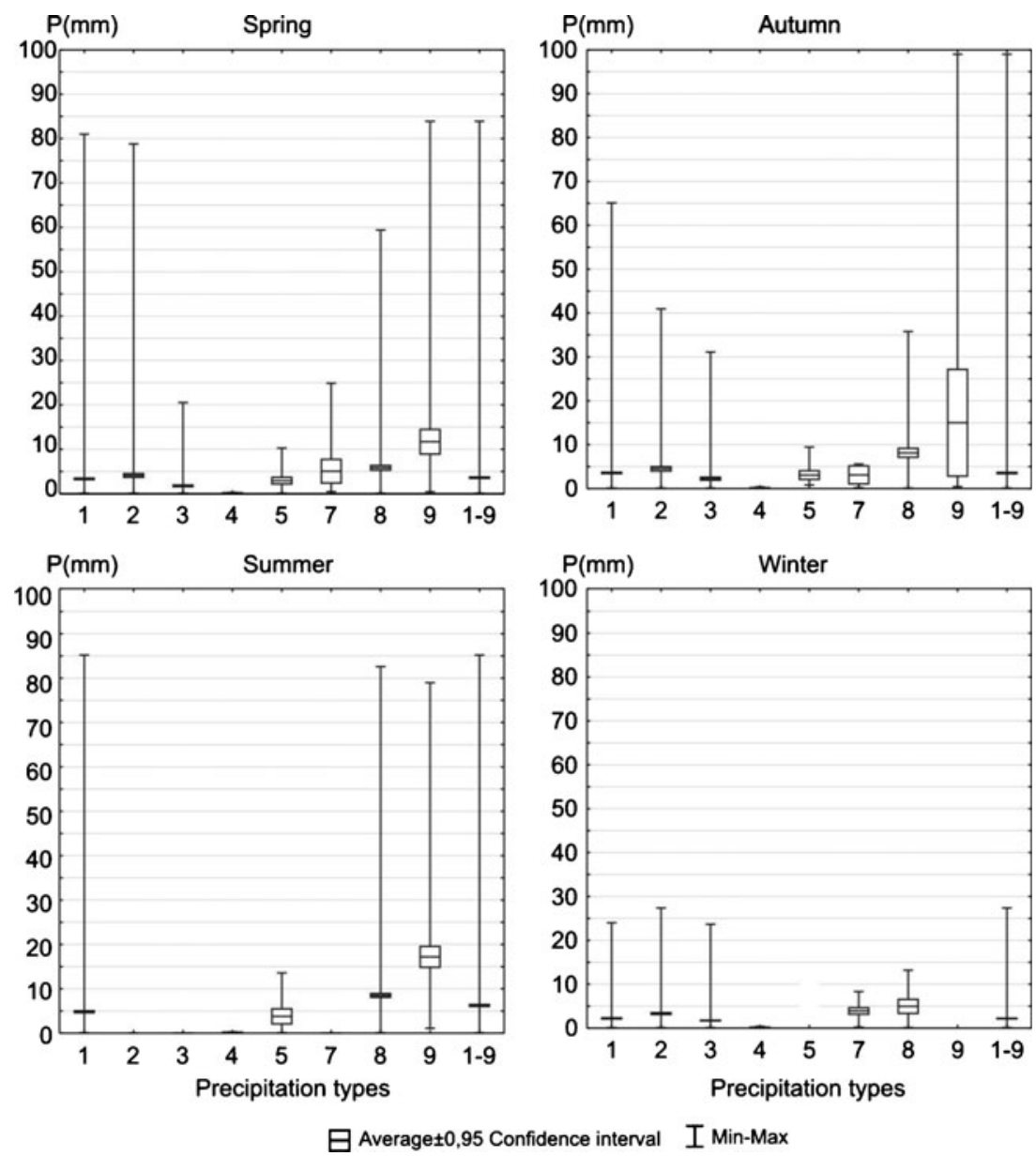
Table 4 Average daily precipitation totals $(\mathrm{mm})$ and mean standard error broken down by precipitation types in Kraków (1863-2008)

\begin{tabular}{|c|c|c|c|c|c|}
\hline Code no. & Spring & Summer & Autumn & Winter & Year \\
\hline 1 & $3.33 \pm 0.08$ & $4.85 \pm 0.12$ & $3.56 \pm 0.08$ & $2.22 \pm 0.06$ & $3.68 \pm 0.05$ \\
\hline 2 & $4.10 \pm 0.21$ & - & $4.50 \pm 0.25$ & $3.32 \pm 0.10$ & $3.77 \pm 0.09$ \\
\hline 3 & $1.71 \pm 0.09$ & - & $2.25 \pm 0.17$ & $1.73 \pm 0.04$ & $1.79 \pm 0.04$ \\
\hline 4 & $0.14 \pm 0.01$ & $0.17 \pm 0.02$ & $0.17 \pm 0.004$ & $0.17 \pm 0.01$ & $0.17 \pm 0.003$ \\
\hline 5 & $2.93 \pm 0.38$ & $3.81 \pm 0.80$ & $3.17 \pm 0.47$ & - & $3.11 \pm 0.28$ \\
\hline 7 & $5.06 \pm 1.29$ & - & $3.12 \pm 0.80$ & $4.02 \pm 0.35$ & $4.26 \pm 0.52$ \\
\hline 8 & $5.84 \pm 0.27$ & $8.52 \pm 0.22$ & $8.15 \pm 0.52$ & $5.04 \pm 0.74$ & $7.84 \pm 0.17$ \\
\hline 9 & $11.70 \pm 1.39$ & $17.22 \pm 1.19$ & $15.01 \pm 5.73$ & - & $14.94 \pm 0.94$ \\
\hline $1-9$ & $3.60 \pm 0.07$ & $6.25 \pm 0.11$ & $3.54 \pm 0.07$ & $2.18 \pm 0.04$ & $3.89 \pm 0.04$ \\
\hline Thunderstorm precipitation $7+8+9$ & $6.5 \pm 0.3$ & $9.04 \pm 0.22$ & $8.5 \pm 0.6$ & $4.39 \pm 0.34$ & $8.29 \pm 0.17$ \\
\hline
\end{tabular}

Air masses identified by T. Niedźwiedź are based on a classification widely adopted in meteorological services (Glossary of Meteorology 2000) and involving source regions (known as a "geographical classification") and thermal and moisture properties (c-continental, $\mathrm{m}$ maritime, w-warm) based on a classification by Bergeron (1928). The author identified six air masses:

- Arctic-A,

- Polar maritime (fresh)_-mPf,

- Polar maritime old (transformed) - mPo,

- Polar maritime warm-mPw,

- Polar continental-cP,

- Tropical-T.

There is also a separate type with various air masses during a day-vAm.

In the classification of atmospheric fronts over southern Poland developed by T. Niedźwiedź, there are four front types:

- Warm,

- Cold,

- Occluded and

- Stationary.

He also identified days with more than one front when several fronts of different types crossed Kraków (various fronts) and front-free days. On days with occluded fronts, no specific distinction was made as to the nature of the occlusion.

\section{Materials and methods}

The study identifies and describes the characteristics of various types of daily precipitation summarised in Table 1. Frequencies of occurrence of circulation types, as well as those of air masses and atmospheric fronts, were presented both annually and seasonally. A seasonal approach seems important in light of earlier research that has found a distinct seasonal aspect in circulation processes.

The influence of atmospheric circulation on precipitation was considered in relation to four precipitation types: liquid, mixed, snow and thunderstorm. The influence was measured with the frequency, conditional probability and average daily totals. The frequency was expressed as a percentage of the number of days with all types of precipitation $>0.1 \mathrm{~mm}$.

The average daily precipitation totals were calculated excluding dry days $(<0.1 \mathrm{~mm})$. Standard errors of the average totals are provided and calculated by dividing the standard deviation by the root square of the sample population. Ninety-five per cent confidence intervals of the average were also identified, as well as maximum daily totals. Because of a naturally strong asymmetry of the daily
Fig. 4 Histograms of daily thunderstorm precipitation in summer, before (left) and after transformation of data by $\log$ transformation (right)
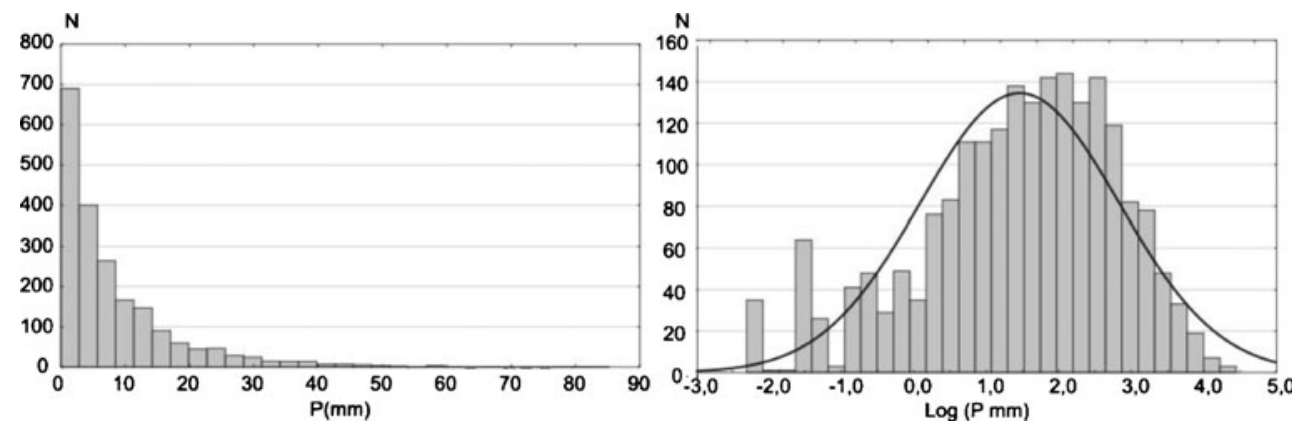
Table 5 Frequency (\%) of circulation types over southern Poland (1873-2008)

\begin{tabular}{|c|c|c|c|c|c|c|}
\hline \multicolumn{2}{|c|}{ Circulation type } & \multirow{2}{*}{$\begin{array}{r}\text { Spring } \\
3.8\end{array}$} & \multirow{2}{*}{$\frac{\text { Summer }}{4.8}$} & \multirow{2}{*}{$\frac{\text { Autumn }}{2.7}$} & \multirow{2}{*}{$\frac{\text { Winter }}{2.4}$} & \multirow{2}{*}{ Year } \\
\hline 1 & $\mathrm{Na}$ & & & & & \\
\hline 2 & $\mathrm{NEa}$ & 4.6 & 4.7 & 2.2 & 2.2 & 3.4 \\
\hline 3 & $\mathrm{Ea}$ & 7.2 & 4.2 & 5.1 & 6.1 & 5.7 \\
\hline 4 & $\mathrm{SEa}$ & 5.2 & 1.9 & 6.2 & 7.1 & 5.1 \\
\hline 5 & $\mathrm{Sa}$ & 2.9 & 1.7 & 4.9 & 3.4 & 3.2 \\
\hline 6 & SWa & 2.6 & 2.2 & 6.5 & 5.5 & 4.2 \\
\hline 7 & Wa & 6.0 & 10.3 & 11.8 & 14.0 & 10.5 \\
\hline 8 & NWa & 4.2 & 6.7 & 5.4 & 5.2 & 5.4 \\
\hline 9 & $\mathrm{Ca}$ & 1.4 & 2.1 & 2.8 & 2.4 & 2.2 \\
\hline 10 & $\mathrm{Ka}$ & 11.0 & 15.7 & 12.0 & 9.4 & 12.0 \\
\hline 11 & $\mathrm{Nc}$ & 3.2 & 3.7 & 1.6 & 1.7 & 2.6 \\
\hline 12 & $\mathrm{NEc}$ & 2.8 & 2.8 & 1.2 & 1.3 & 2.0 \\
\hline 13 & $\mathrm{Ec}$ & 3.7 & 1.7 & 1.8 & 1.9 & 2.3 \\
\hline 14 & $\mathrm{SEc}$ & 4.0 & 1.6 & 2.2 & 2.6 & 2.6 \\
\hline 15 & $\mathrm{Sc}$ & 3.9 & 1.4 & 3.5 & 3.2 & 3.0 \\
\hline 16 & SWc & 5.6 & 2.5 & 5.9 & 6.3 & 5.1 \\
\hline 17 & $\mathrm{Wc}$ & 8.5 & 10.1 & 10.6 & 12.8 & 10.5 \\
\hline 18 & NWc & 5.1 & 6.8 & 4.0 & 4.9 & 5.2 \\
\hline 19 & $\mathrm{Cc}$ & 1.4 & 1.2 & 0.8 & 0.7 & 1.0 \\
\hline 20 & $\mathrm{Bc}$ & 11.0 & 12.5 & 7.0 & 5.3 & 9.0 \\
\hline 21 & $X$ & 2.0 & 1.3 & 1.6 & 1.5 & 1.6 \\
\hline $1-21$ & Total & 100.0 & 100.0 & 100.0 & 100.0 & 100.0 \\
\hline 01-10 & $\mathrm{a}$ & 49.0 & 54.5 & 59.7 & 57.8 & 55.2 \\
\hline $11-20$ & $\mathrm{c}$ & 49.1 & 44.2 & 38.8 & 40.7 & 43.2 \\
\hline
\end{tabular}

The highest values are indicated in bold

precipitation distribution, a log transformation was applied to minimise the skewness of the outcome distributions. This allowed the application of the Student's $t$ test for the assessment of the significance of differences between daily precipitation averages.

In its general form, conditional probability expresses the likelihood of the occurrence of a given random event subject to the occurrence of another random event. The study calculated conditional probabilities of the occurrence of precipitation, i.e. the number of days with a certain type of precipitation in a given circulation type/air mass/front in relation to the number of days with a given circulation type/ air mass/front. Precipitation characteristics were also identified separately on days with and without a front. The analysis of the influence of circulation on precipitation was performed on an annual and seasonal scale and within these categories also for each circulation type, air masses and atmospheric front.

\section{Results}

4.1 Frequency, probability and average totals by type of precipitation

In Kraków, precipitation is recorded on 174.2 days per year on average (Table 2), which means that the probability of a day with precipitation is $48 \%$. In winter and in summer, precipitation frequencies are slightly higher than in the transitional seasons. All types of precipitation revealed a strong seasonality. Days with liquid precipitation (rain and drizzle) are a dominant group and account for $58.1 \%$ of all precipitation days. In summer, almost all precipitation is liquid, whilst in winter, its share drops to about one third of all days with precipitation. In winter, the snowfall accounts for the largest number of precipitation days at $46.4 \%$ of the total. Snowfall often occurs during the transitory seasons, especially in spring. If the current trend of air temperature growth continues, then southern Poland can be expected to receive less snowfall and the snowfall will yield less water. A $1{ }^{\circ} \mathrm{C}$ increase in the average temperature in winter in Kraków corresponded to a 3.5-day drop in the number of snowfall days and a 6.1-mm drop in snowfall total (Twardosz 2010b). Based on the HadCM2 GS climate model, it is predicted that precipitation may increase in our climate zone as the climate warms up (Kożuchowski 2004). The predicted precipitation increase is estimated at approximately 30\%, which means that the changing climate may result in a growing frequency and quantity of liquid precipitation.

The third most frequent type of precipitation in Kraków is thunderstorm precipitation, which is an important type
Table 6 Frequency (\%) of days with particular air masses over southern Poland (1951-2008)

\begin{tabular}{lrrrrr}
\hline Air masses & Spring & Summer & Autumn & Winter & Year \\
\hline Arctic-A & 11.5 & 3.1 & 8.6 & 8.9 & 8.0 \\
Polar maritime (fresh)—mPf & 13.6 & 25.7 & 16.7 & 14.0 & 17.5 \\
Polar maritime old (transformed)_mPo & 31.2 & 35.6 & 31.3 & 32.7 & 32.7 \\
Polar maritime warm—-mPw & 6.5 & 3.6 & 10.1 & 9.4 & 7.4 \\
mP (mPf+mPo+mPw) & $\mathbf{5 1 . 3}$ & $\mathbf{6 4 . 8}$ & $\mathbf{5 8 . 1}$ & $\mathbf{5 6 . 2}$ & $\mathbf{5 7 . 6}$ \\
Polar continental-cP & 23.4 & 18.7 & 20.1 & 23.6 & 21.4 \\
Tropical-T & 3.7 & 4.3 & 3.4 & 1.0 & 3.1 \\
Various air masses—vAm & 10.0 & 9.2 & 9.8 & 10.4 & 9.8 \\
\hline
\end{tabular}


Table 7 Frequency (\%) of days with particular types of atmospheric front over southern Poland (1951-2008)

\begin{tabular}{lrrrrr}
\hline Type of front & Spring & Summer & Autumn & Winter & Year \\
\hline Warm & 9.2 & 5.4 & 8.6 & 9.8 & 8.2 \\
Cold & 15.9 & 19.5 & 16.7 & 14.2 & 16.6 \\
Occluded & 5.8 & 4.8 & 4.3 & 7.4 & 5.6 \\
Stationary & 1.5 & 2.1 & 1.4 & 1.2 & 1.5 \\
Various fronts & 8.6 & 7.0 & 7.4 & 9.4 & 8.1 \\
Total days with fronts & 41.0 & 38.7 & 38.3 & 42.0 & 40.0 \\
\hline
\end{tabular}

because of its intensity. Thunderstorm precipitation is a result of deep convection processes in the lower troposphere. It occurs throughout the year, but is at its most frequent in summer. Thunderstorms were recorded on average on $33.9 \%$ of all days with precipitation during that season. There was, however, no simple relationship between the temperature and thunderstorm precipitation. Research (Twardosz 2010b) shows that a growing convection caused by a temperature increase did not translate into either higher frequency or totals of thunderstorm precipitation. Indeed, only $2 \%$ of the variances of the thunderstorm precipitation totals in Kraków were accounted for by the summertime air temperature variability. This may be explained by the fact that the warmest summers in Poland are also the driest ones and the dryness works against the development of thunderstorms.

Mixed precipitation accounted for $9.6 \%$ of precipitation days during the year. Whilst it is greatly concentrated in winter and in transitional seasons, there were two cases of mixed precipitation (rain and snow) in June, i.e. in 1881 (11 June) and 1933 (8 June), all of which were accounted for and documented in detail in the weather station's records.

In the autumn and winter seasons, horizontal precipitation, i.e. deposits of fog with rime, is quite frequent. This mostly occurs at night and in the morning when the night cooling effect is at its strongest and when water vapour condenses and crystallises or water droplets impinge on cooled objects. The overall share of this type of precipitation in the total precipitation, however, is negligible (Table 3 ).

Among all precipitation types, the greatest contribution to the annual total is provided by liquid and thunderstorm precipitation coded 1 and 8 (Table 3). Combined, these two codes account for $78.6 \%$ of the annual total and nearly $94 \%$ in summer.

The main characteristics of precipitation totals are detailed in Fig. 3 and Table 4. In order to fulfil the necessary assumptions for the statistical test for the significant differences of the averages, the variables have to be at least approximately normally distributed. Since it is natural for precipitation daily data to have a skew distribution, the $\log$ transformation has been applied. For the example given in Fig. 4, the asymmetry coefficient of the daily thunderstorm precipitation in summer is 2.4 , whilst after transformation, it is -0.63 . It is, of course, not exactly zero; however, the negative value can be attributed to the relatively large number of days with the very small precipitation identified at $0.1 \mathrm{~mm}$. This can be seen in the right histogram with the normal curve fitted. Despite the Shapiro-Wilk statistic of 0.96, which corresponds to a significant disparity of distributions, it may be assumed that the disparity has no major significance for the application of the Student's $t$ test because with so much data, the Shapiro-Wilk is too sensitive.

The average daily summer precipitation is nearly two times greater than in winter (Table 4 and Fig. 3). In spring, average daily precipitation is slightly higher and statistically different from the average precipitation in winter $(p<0.001)$. A large variation of precipitation totals is visible especially in the breakdown into precipitation types, e.g. thunderstorm precipitation yields more water in autumn than in spring and the average precipitation totals differ between these seasons at a statistically significant level $(p<0.001)$. Indeed, in Kraków, the highest daily precipitation total was recorded in autumn when, on 9 September 1963, a thunderstorm with hail produced $99 \mathrm{~mm}$ of rain (Fig. 3).

Thunderstorms with hail and rain are known to produce some of the largest totals of all precipitation types, and their summer daily average is $17.2 \mathrm{~mm}$. A thunderstorm without hail in summer produces only half of that figure at $8.5 \mathrm{~mm}$. The differences between averages of these two precipitation types are statistically significant $(p<0.001)$.

\subsection{Frequency of circulation types, air masses and atmospheric fronts}

As shown in Table 5, anticyclonic circulation is more frequent in southern Poland than cyclonic circulation, except in spring when the two have a similar frequency. Among the 21 circulation types considered in this study, the most frequent was the anticyclonic wedge, at $12 \%$, followed by types involving western advection, i.e. Wa and $\mathrm{Wc}$, at $10.5 \%$ each, and the cyclonic trough $\mathrm{Bc}$, at $9 \%$. These four circulation types combined account for $43 \%$ of days in the year. At the other end of the spectrum, the cyclone centre $\mathrm{Cc}$ is among the least frequent of types at $1 \%$ of all days.

The Ka type is the most frequent seasonally and dominates in summer, autumn and spring. Only in winter did the $\mathrm{Wa}(14.0 \%)$ and $\mathrm{Wc}(12.8 \%)$ types took precedence. 

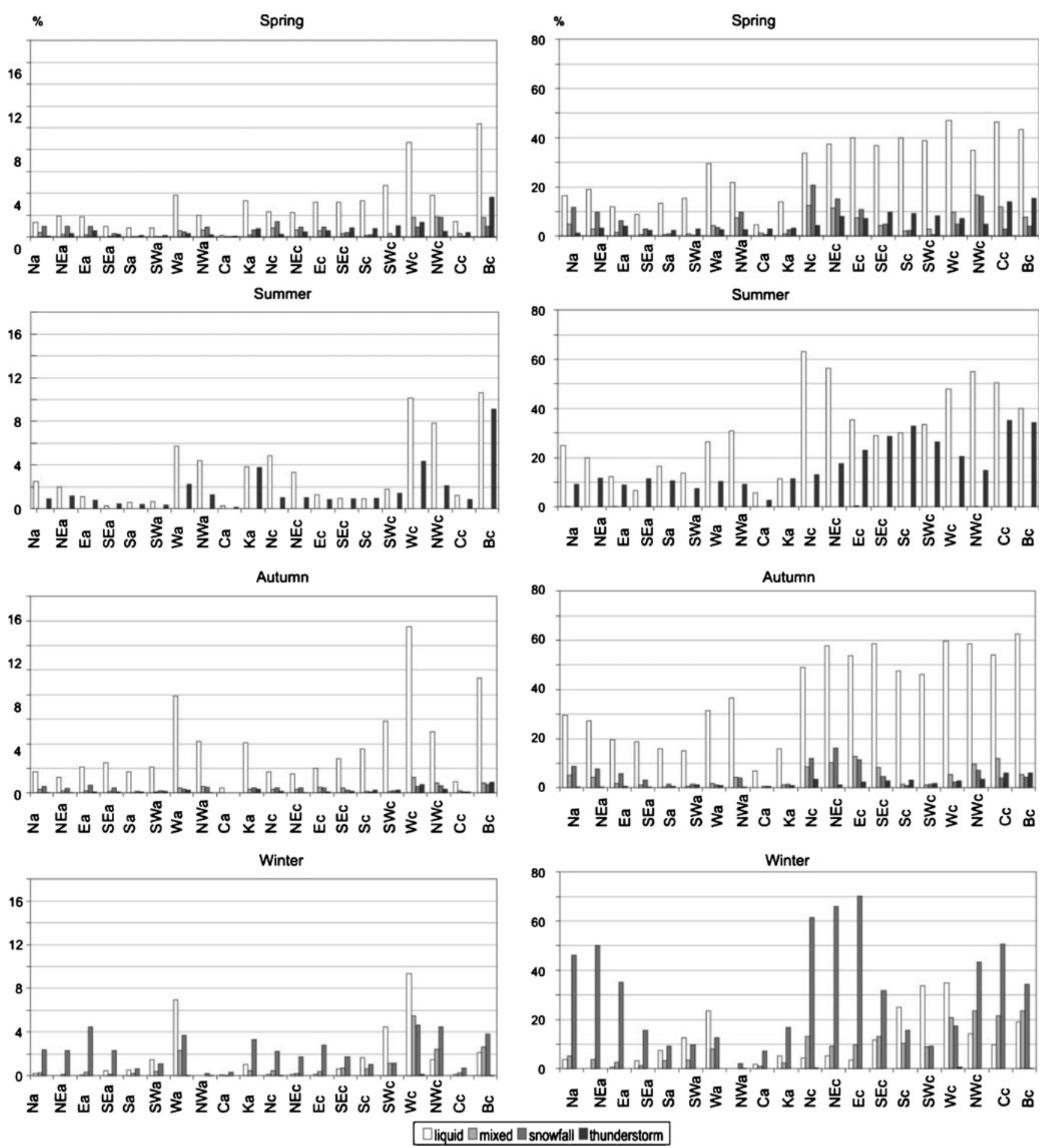

Fig. 5 Frequency (left) and conditional probability (right) of precipitation (seasonal) by circulation types in Kraków (1873-2008)

A characteristic feature of atmospheric circulation in southern Poland is an advection sector variation between seasons. For example, in spring, situations with air advection from the eastern sector are most frequent, in summer from the northern sector and in autumn from the south.

Air masses flowing into southern Poland display a variety of thermal and moisture properties. On $57.6 \%$ of days of the year, the weather is influenced by maritime Polar air (Table 6). This air mass was found to dominate over the entire Polish territory (Bołaszewska and Reutt 1962). Statistically, on $21.4 \%$ of days of the year does southern Poland receive continental polar air from Eastern Europe. Air masses from outside of the moderate latitudes are far less frequent in the area, i.e. arctic air on $8.0 \%$ of 
Fig. 6 Statistics of daily totals of thunderstorm precipitation in summer and of snowfall in winter by circulation types in Kraków (1873-2008)

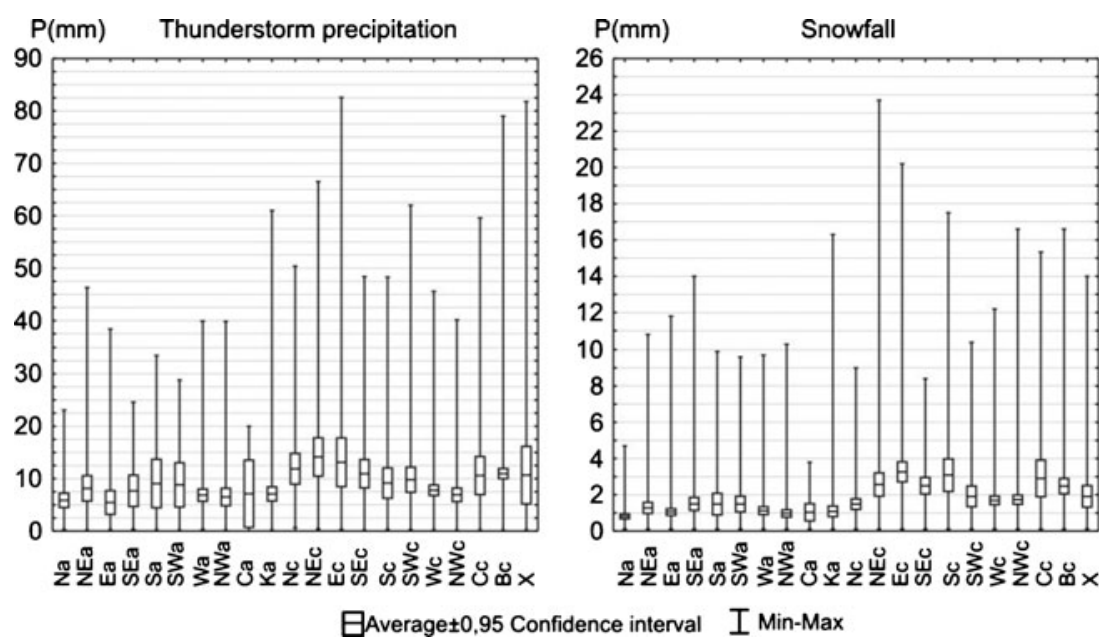

days and tropical air on $3.1 \%$ of days. As with sectors of advection, there is also a distinct seasonal variation in air mass types. Maritime Polar air is the most frequent in summer. Continental polar air arrives primarily in winter and spring. Arctic air advection peaks in spring (11.5\%). Tropical air is most frequent in spring and summer. Springtime also stands out in having the greatest share of air masses from other geographical zones (i.e. arctic and tropical), the effect of which is that spring weather has the greatest variability. During each of the seasons, there is more than one type of air on approximately $10 \%$ of days.

There is a great deal of variability in air advection sector in mid-latitudes which is evidenced by a high frequency of atmospheric fronts. In the study area, fronts occur on approximately $40 \%$ of days of the year (Table 7). Cold fronts are more frequent than warm fronts in every season, with the maximum frequency in summer, occurring on $19.5 \%$ of days, and the minimum frequency in winter, occurring on $14.2 \%$ of days. On average, warm fronts occur half as frequently as cold fronts and are least frequent in summer at $5.4 \%$ and most frequent in winter at $9.8 \%$. This seasonal distribution of the front frequency is characteristic of the temperate climate zone, as a result of seasonal differences in temperature variation between the land surface and the ocean. The frequency of more than one front per day is quite high in all seasons. Stationary fronts are very rare over southern Poland and account for just $1.5 \%$ days.

\subsection{Precipitation and circulation pattern}

\subsubsection{Precipitation and circulation types}

Temperate zone cyclones arrive in Europe from over the Atlantic carrying moist air that favours precipitation. In this circulation, liquid precipitation occurs most frequently in spring, summer and autumn, whilst in winter, it mostly produces snowfall (Fig. 5 left). In anticyclonic types, precipitation is less frequent. In summer, precipitation during anticyclonic situations produces half of what it does in cyclonic situations. The pattern is similar with summer thunderstorm precipitation: $22.5 \%$ during cyclonic and $11.5 \%$ during anticyclonic situations (air mass thunderstorm).

Thunderstorm precipitation, as well as liquid and mixed precipitation types, displays a strong relationship with certain types of cyclonic circulation. Nearly $30 \%$ of all days with precipitation during the year occur in either of the two cyclonic situations, Wc $15.5 \%$ and Bc $14 \%$. A majority of this $30 \%$ ( $18 \%$ of precipitation) is accounted for by liquid precipitation. It is similar in the seasonal figures, but in spring and summer, type $\mathrm{Bc}$ produces more rainfall than type Wc (Fig. 5 left), whilst in winter the cyclonic types produces less precipitation and western cyclonic situations produce distinctly more precipitation.

On average during the whole year, there is more liquid precipitation than other forms of precipitation in 19 out of the 21 circulation types. The only exception is the Ea type where there is slightly more snowfall. Rainfall is also the most common form of precipitation in spring and autumn in all circulation types, whilst in summer there are two circulations, i.e. SEa and Sc, that feature more thunderstorm precipitation than liquid precipitation.

Winter has the most diverse picture of precipitation frequencies (Fig. 5, left). Snowfall dominates in 15 circulation types. NW-SE air flow advection sectors and the $\mathrm{Cc}$ and $\mathrm{Bc}$ types dominate, whilst the NW anticyclonic circulation brings only snowfall.

In general, precipitation frequency varies greatly between circulation types especially in rainfall and thunderstorm precipitation types. This variation is the greatest in three types (Wa, Wc or Bc), depending on the season, and the smallest in anticyclonic types. There is no single dominant circulation type in the case of snowfall and mixed precipitation because 
Fig. 7 Average daily precipitation totals with $95 \%$ confidence interval by circulation types in Kraków (1873-2008)

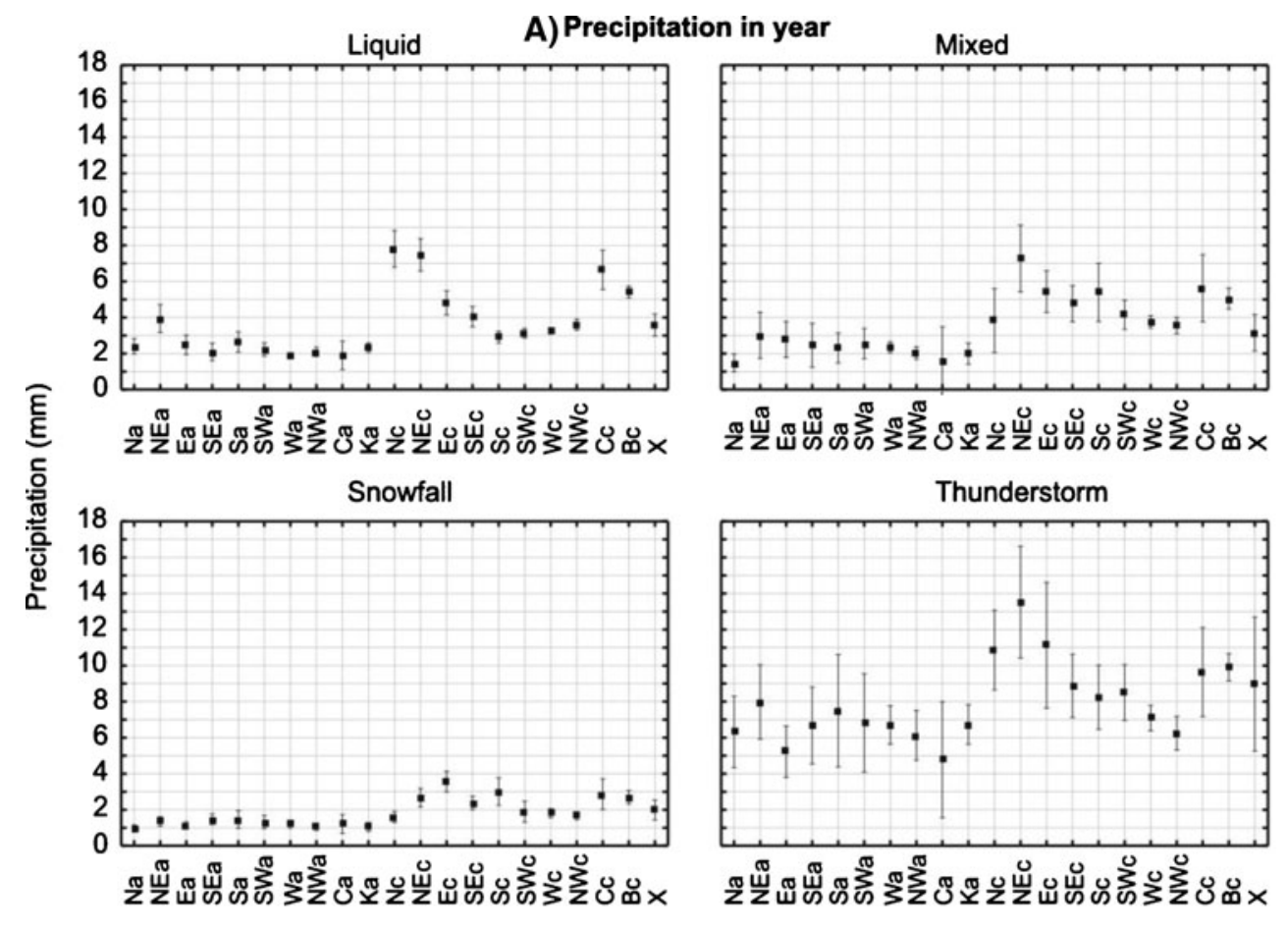

B) Liquid precipitation by seasons

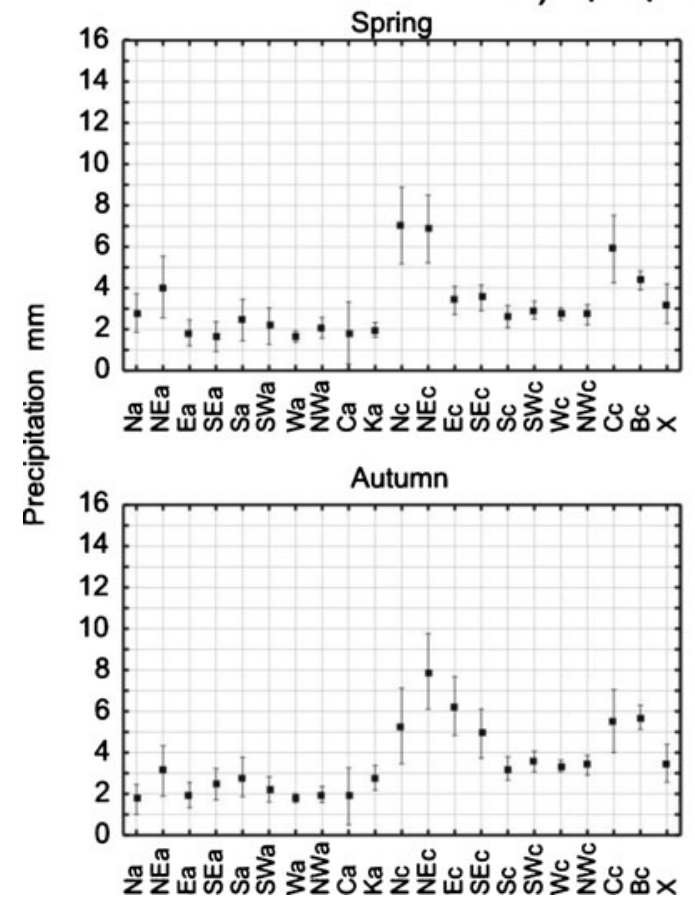

Summer

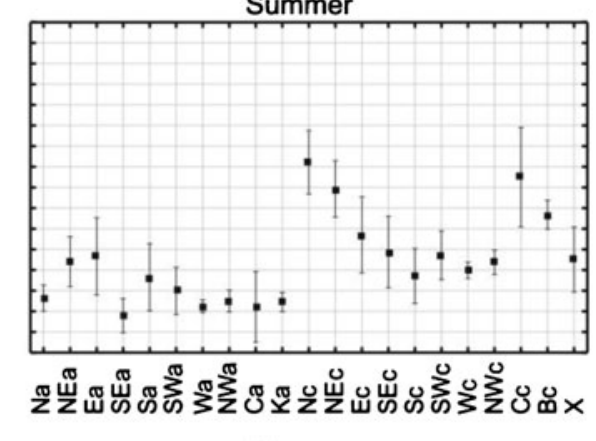

Winter

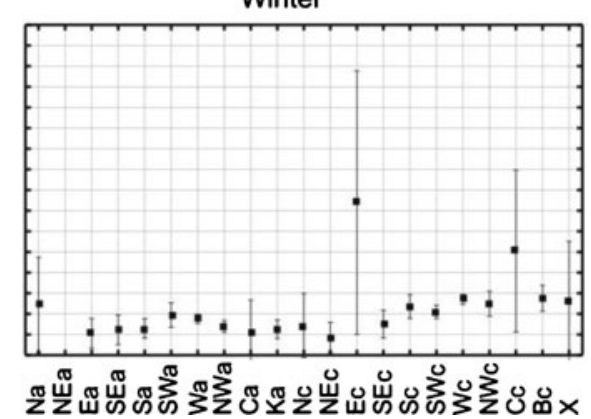

air temperature comes into play alongside moisture conditions as a factor controlling the formation of snow.

Conditional probability is a better characteristic for the assessment of the impact of circulation on precipitation as it takes into account the number of occurrences of a given circulation type. Because of the fact that the influence of circulation on the occurrence of different forms of precipitation changes during the course of the year, the authors only calculated the precipitation probabilities for each circulation type in the seasonal breakdown.

All types of precipitation were more probable in the cyclonic circulation types than in anticyclonic types (Fig. 5, right). In autumn, more than one in two liquid precipitation days were accounted for by a cyclonic circulation type. In spring and autumn, liquid precipitation showed greater probabilities than other forms of precipitation in each of the 
Fig. 8 Conditional probability of precipitation (seasonal) by air masses in Kraków (1951-2008)
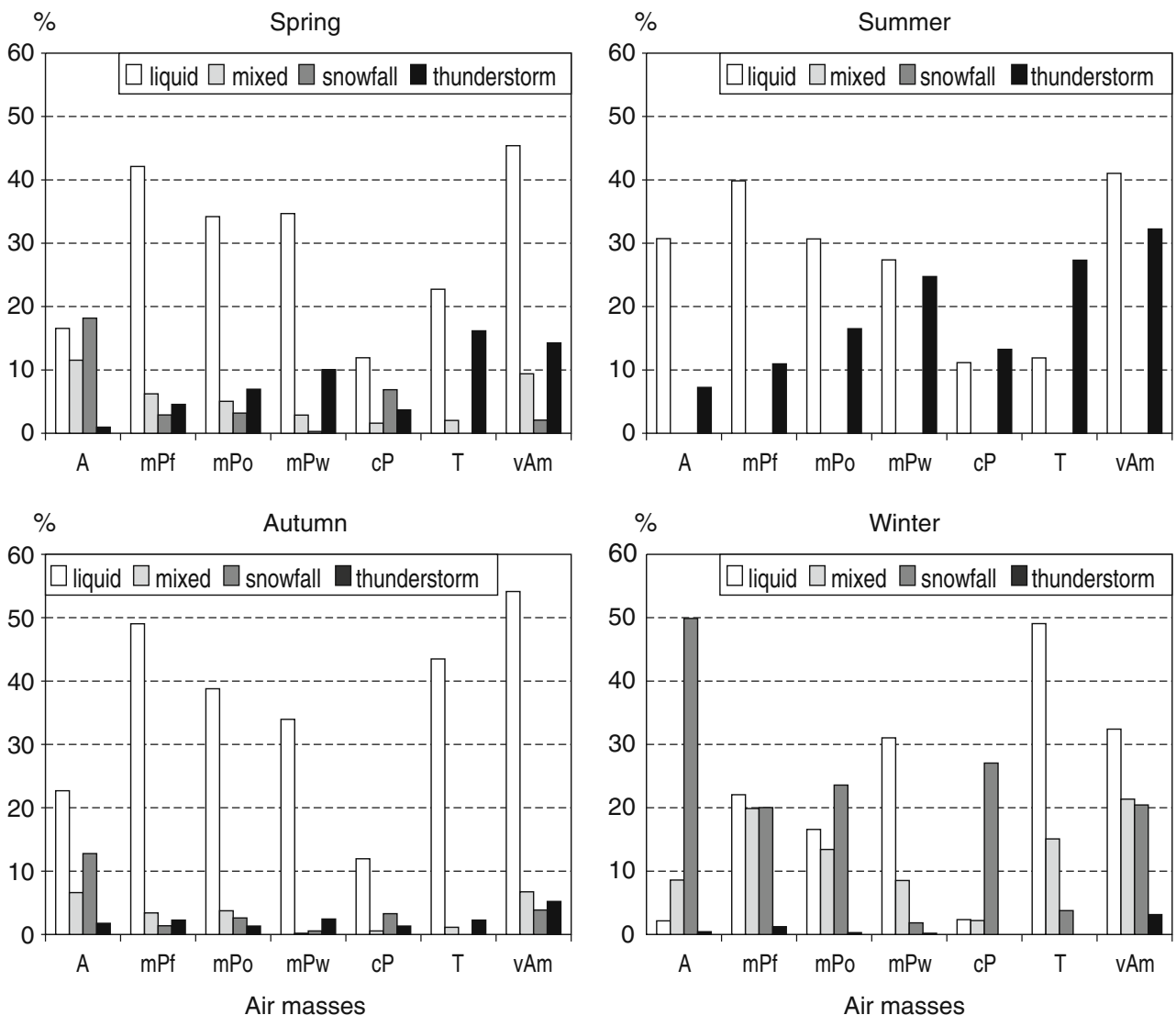

21 circulation types. The same pattern was seen in 18 circulation types in summer and in five types in winter (Fig. 5, right). The highest probabilities of more than 50\% of liquid precipitation days were calculated for four circulation types (Nc, NEc, NWc and $\mathrm{Cc}$ ) in summer and for seven types (NEc, Ec, SEc, Wc, NWc, Cc and Bc) in autumn. Similarly high probabilities were also found for winter snowfall in five circulation types (NEa, Nc, NEc, Ec and $\mathrm{Cc}$ ). The highest probability value of $70 \%$ was calculated for winter snowfall in an eastern cyclonic circulation, and the probability of precipitation, regardless of the form of precipitation, in this circulation type was $83 \%$. An even higher probability of any precipitation of $85 \%$ was calculated for both the Cc circulation type in summer and the NEc in autumn.

The highest probability of mixed precipitation is $17 \%$ in the NWc type in spring, $13 \%$ in the Ec type in autumn and $24 \%$ in the NWc and Bc types in winter. The two top circulation types with regards to the probability of thunderstorm precipitation are $\mathrm{Bc}$ and $\mathrm{Cc}$ at approx. 35\%, followed by the Sc type, which is only slightly lower.

The variation of the daily precipitation totals in circulation types are illustrated with the examples of thunderstorm precipitation in summer and snowfall in winter (Fig. 6). The average totals of the four types of precipitation broken down into circulation types are summarised on an annual basis (Fig. 7a). Liquid precipitation is presented in all seasons (Fig. 7b).

Thunderstorm precipitation is among the types of precipitation producing the highest total regardless of the circulation types (Fig. 7a). The highest average figures, in excess of $10 \mathrm{~mm}$ annually (Fig. 7a) and $12 \mathrm{~mm}$ in summer (Fig. 6), were recorded in three circulation types-Nc, NEc and Ec-followed by $\mathrm{Cc}$ and Bc. These circulation types account also for high totals of liquid precipitation in summer and in transitional seasons (Fig. 7b). Precipitation in two of these types, i.e. Nc and NEc, caused serious floods in southern Poland (e.g. Cebulak 1992; Twardosz and Niedźwiedź 2001). The Carpathian Mountain range assists in the formation of high-yield precipitation in southern Poland. On contact with this formidable barrier, wet air masses arriving from $\mathrm{N}$ and $\mathrm{NE}$ produce intensive and long-duration rains in the mountains and in their foreland as an effect of orographic lifting.

The NEc type is also responsible for the highest average daily totals of mixed precipitation. In winter, it is type Ec, which clearly produces the highest precipitation totals of both liquid and mixed types of precipitation. However, because of the statistically small sample size of the liquid precipitation occurring in the Ec type ( 8 days), the average error margin is very wide. The Sc and Cc situation types are among those favourable to high snowfall totals. 
Fig. 9 Average daily liquid precipitation totals with $95 \%$ confidence interval (a) and statistics of daily totals of thunderstorm precipitation and snowfall by air masses in Kraków (1951-2008)
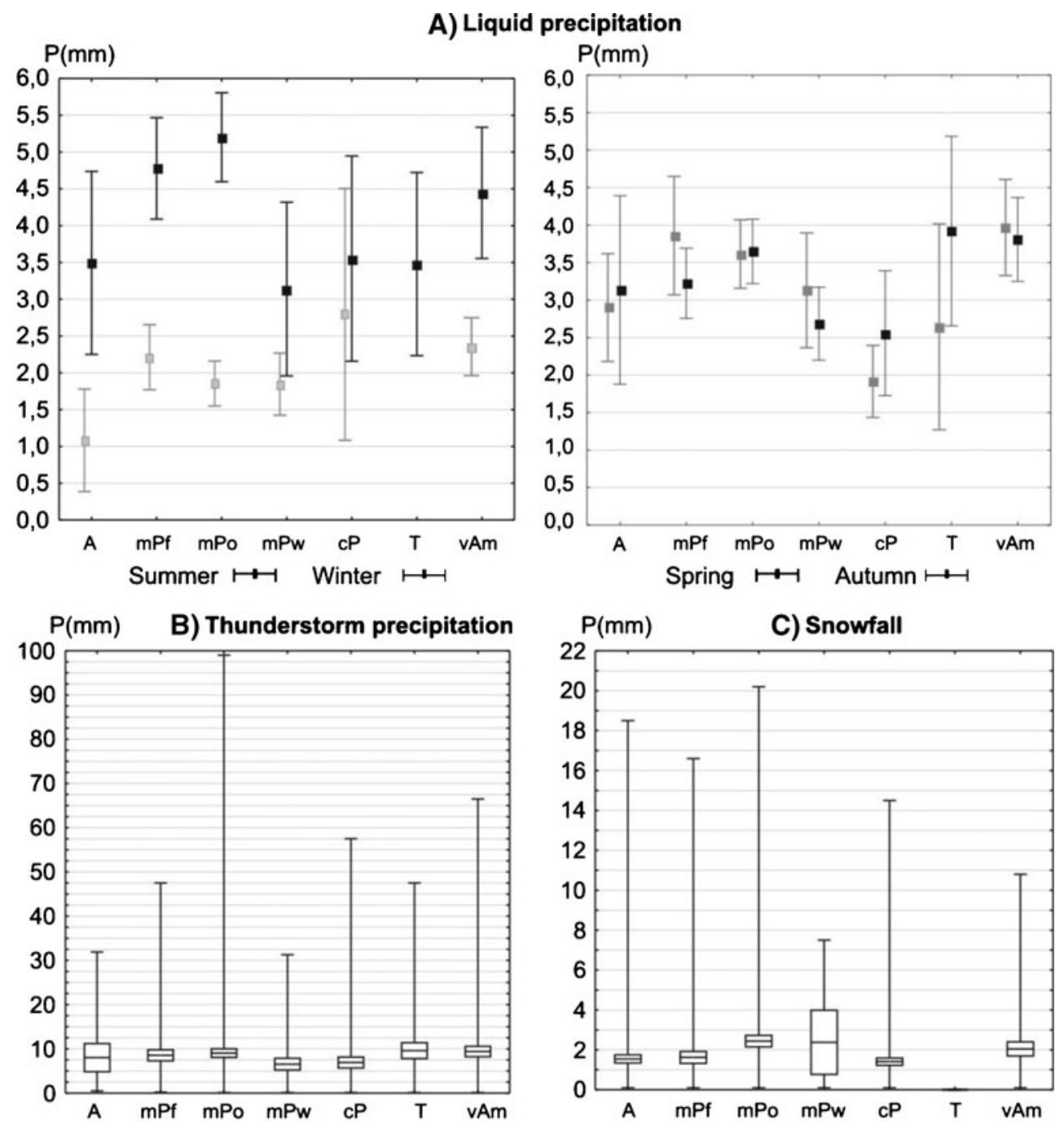

曰Average $\pm 0,95$ Confidence interval I Min-Max

Table 8 Air mass precipitation and frontal precipitation characteristics in Kraków (1951-2008)

\begin{tabular}{|c|c|c|c|c|c|c|c|c|c|c|}
\hline \multirow[t]{2}{*}{ Precipitation types } & \multicolumn{3}{|l|}{ Spring } & \multicolumn{2}{|c|}{ Summer } & \multicolumn{2}{|c|}{ Autumn } & \multicolumn{2}{|c|}{ Winter } & Year \\
\hline & $\mathrm{am}$ & $\mathrm{f}$ & $\mathrm{a}$ & $\mathrm{f}$ & am & $\mathrm{f}$ & an & $\mathrm{f}$ & am & $\mathrm{f}$ \\
\hline \multicolumn{11}{|c|}{ Frequency ( $\%$ of all day precipitation $\geq 0.1 \mathrm{~mm}$ ) } \\
\hline Liquid & 23.7 & 38.4 & 31.2 & 33.0 & 33.5 & 45.8 & 9.8 & 20.8 & 24.0 & 34.0 \\
\hline Mixed & 4.1 & 7.4 & - & - & 2.7 & 4.4 & 6.5 & 15.7 & 3.4 & 7.2 \\
\hline Snowfall & 8.3 & 3.2 & - & - & 4.8 & 2.5 & 26.8 & 18.4 & 10.5 & 6.5 \\
\hline thunderstorm & 4.5 & 9.5 & 14.3 & 21.4 & 1.4 & 3.2 & 0.1 & 1.1 & 0.4 & 8.7 \\
\hline \multicolumn{11}{|c|}{ Mean daily totals (mm) } \\
\hline Liquid & $3.3 \pm 0.3$ & $3.5 \pm 0.2$ & $3.9 \pm 0.2$ & $5.4 \pm 0.3$ & $2.8 \pm 0.2$ & $3.8 \pm 0.2$ & $1.8 \pm 0.1$ & $2.2 \pm 0.1$ & $3.2 \pm 0.1$ & $3.8 \pm 0,1$ \\
\hline Mixed & $3.6 \pm 0.5$ & $4.2 \pm 0.4$ & - & - & $3.8 \pm 0.7$ & $4.6 \pm 0.5$ & $2.5 \pm 0.2$ & $3.6 \pm 0.2$ & $3.0 \pm 0.2$ & $3.9 \pm 0.2$ \\
\hline Snowfall & $1.7 \pm 0.2$ & $1.8 \pm 0.3$ & - & - & $2.1 \pm 0.3$ & $2.6 \pm 0.4$ & $1.5 \pm 0.1$ & $2.3 \pm 0.1$ & $1.6 \pm 0.1$ & $2.2 \pm 0.1$ \\
\hline thunderstorm & $5.0 \pm 0.5$ & $7.0 \pm 0.5$ & $7.9 \pm 0.5$ & $10.6 \pm 0.6$ & $5.4 \pm 0.9$ & $9.3 \pm 1.4$ & - & $4.6 \pm 0.5$ & $7.0 \pm 0.4$ & $9.3 \pm 0.3$ \\
\hline
\end{tabular}

am air mass precipitation, $f$ frontal precipitation 
Fig. 10 Conditional probability of precipitation (seasonal) by fronts in Kraków (1951-2008)
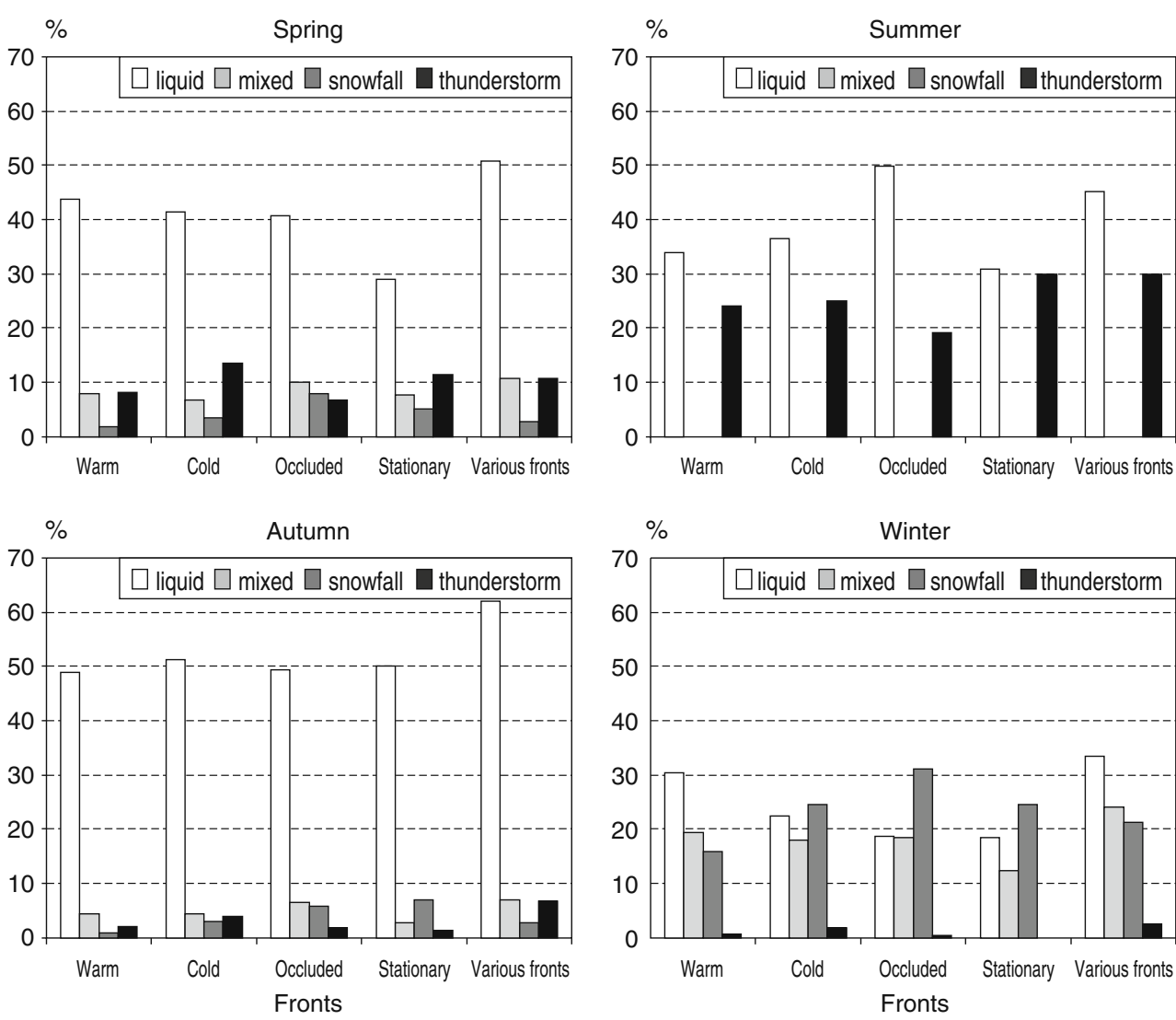

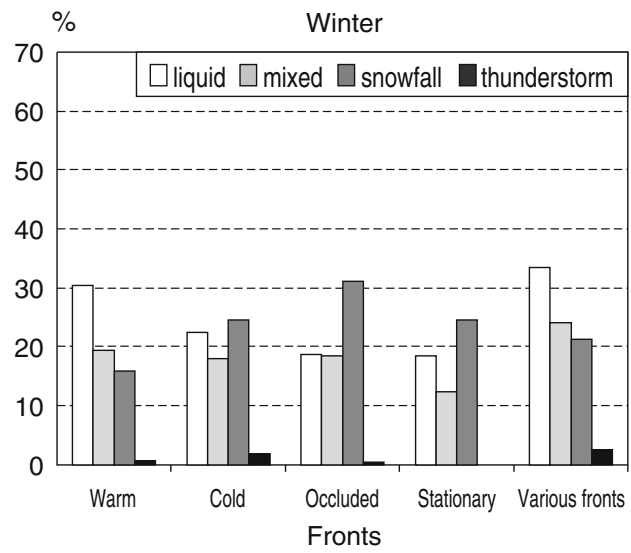

\subsubsection{Precipitation and air masses and fronts}

It is also interesting to investigate an influence of air masses and fronts on the occurrence of precipitation. The highest number of days with precipitation during the year, regardless of its type or form, occurs in the old marine Polar air masses (mPo), which is largely a result of a high frequency of occurrence of these wet air masses in southern Poland. Liquid precipitation is the most frequent in most air mass types, except for continental and arctic air masses which are more conducive to snowfall.

In spring, all air masses mainly produce liquid precipitation, with the exception of cold arctic air that mainly produces snowfall (Fig. 8). In winter, the pattern is distinctly different. The highest conditional probability of $50 \%$ was found for winter snowfall in arctic air (Fig. 8). A similar probability figure was calculated for wintertime liquid precipitation in tropical air. In autumn, the greatest probability of 54\% was determined for liquid precipitation in air masses from various sectors followed by $49 \%$ in maritime Polar fresh air. In spring and summer, liquid precipitation reaches the highest probabilities of more than $40 \%$ in various air masses and in maritime Polar fresh air. In summer, the highest probabilities of thunderstorm precipitation were determined in various air masses $(32 \%)$, in tropical air $(27 \%)$ and warm maritime Polar air (25\%).
Average precipitation totals that depend on the kind of air mass differ little between seasons. The differences become much more pronounced for summer liquid precipitation with the highest figures determined for old maritime Polar air $(5.2 \mathrm{~mm})$, fresh maritime Polar air $(4.8 \mathrm{~mm})$ and on days with different air masses $(4.4 \mathrm{~mm}$; Fig. 9a). In spring and autumn, there are no statistically significant differences in the average totals of liquid precipitation in any air masses.

There is not much variation in thunderstorm precipitation depending on the type of air mass (Fig. 9b). Snowfall probability dominates in arctic and continental polar air masses, but produces the lowest totals because of the low moisture content carried by these air masses.

Table 8 summarises the characteristics of precipitation studied with the distinction made between frontal and nonfrontal precipitation. Cyclones moving from the Atlantic into Europe carry extensive systems of atmospheric fronts, which means that most liquid, mixed and thunderstorm precipitation falls on days when a front is moving over the area affected. Snowfall is an exception as it mostly occurs in uniform air masses (Table 8a). In winter, both warm and cold fronts tend to cause temperature increases and therefore favour liquid precipitation.

Frontal precipitation, regardless of its type, normally produces higher totals because of moisture contents that are 
Fig. 11 Average daily liquid precipitation totals with $95 \%$ confidence interval (a) and statistics of daily totals of thunderstorm precipitation (b) and snowfall (c) by fronts in Kraków (1951-2008)
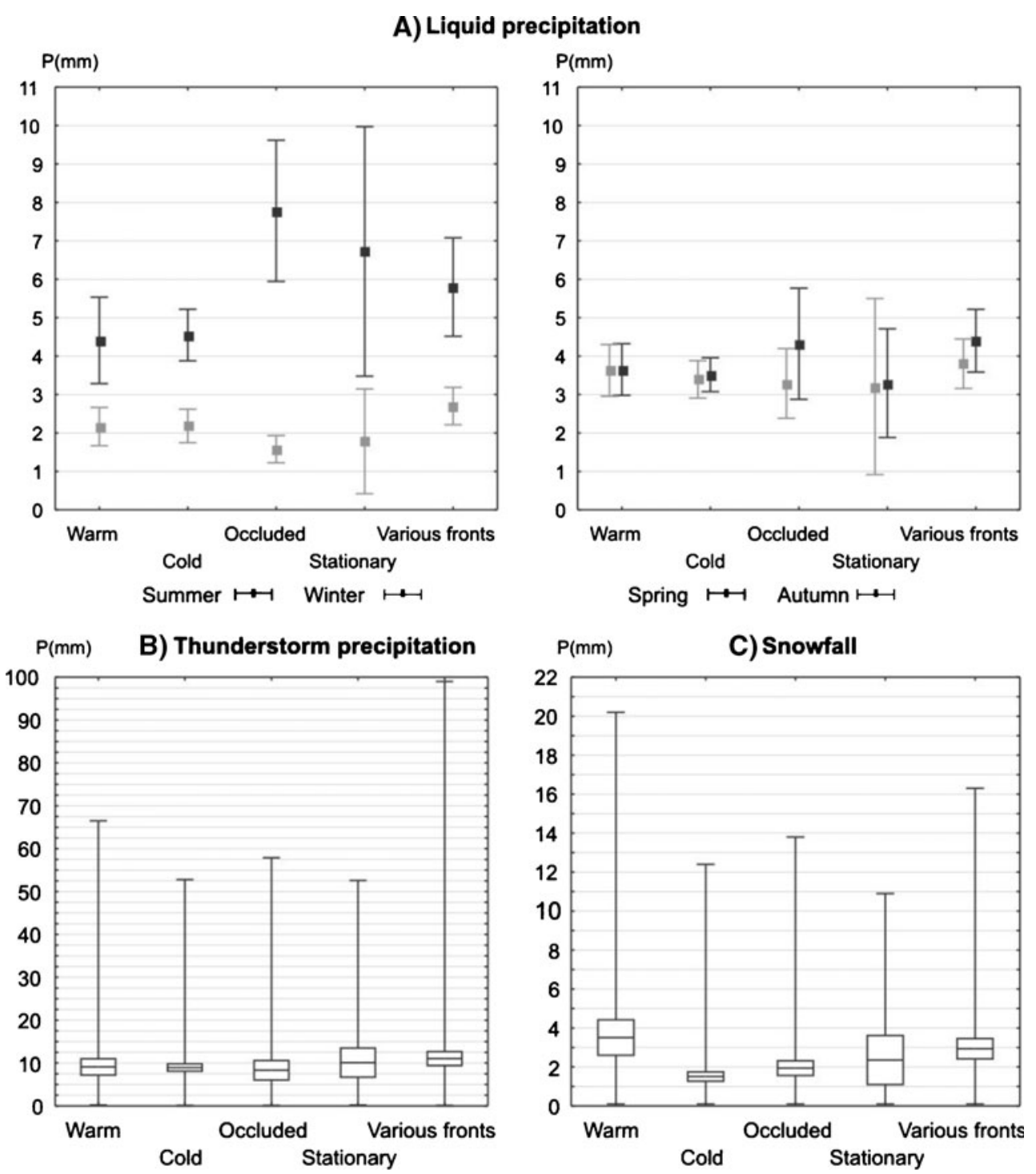

Average $\pm 0,95$ Confidence interval I Min-Max

greater in frontal zones than in uniform air masses (Table 8b). In summer, the highest totals of frontal thunderstorm precipitation are higher at $10.6 \mathrm{~mm}$ than the air mass precipitation at $7.9 \mathrm{~mm}$.

During all seasons except winter, the form of precipitation associated with every type of cold front is most likely to be liquid precipitation (Fig. 10). In autumn, the probability of liquid precipitation exceeds $60 \%$ on days with several fronts and is only slightly lower at $50 \%$ on days with all other types of front. In summer, the greatest probability of precipitation is on days on which there is an occluded front, whilst in spring it is the most probable on days with more than one front. In winter, snowfall has $31 \%$ probability on days with an occluded front, whilst liquid precipitation has $33 \%$ probability on days with more than one front and $30 \%$ on a day with a warm front. The greatest probability of summer thunderstorm precipitation $(30 \%)$ is calculated to occur on days with stationary fronts and on days with more than one front.

The highest average daily totals of liquid precipitation were recorded in summer (Fig. 11a) during the passage of occluded fronts $(7.8 \mathrm{~mm})$ and on days with stationary fronts $(6.7 \mathrm{~mm})$. Frontal thunderstorms are also some of the most productive types of precipitation, especially when they occur on days with more than one front $(10.8 \mathrm{~mm})$ or on days with a stationary front (10.1 mm; Fig. 11). Snowfall precipitation is the highest on days with a warm front.

\section{Conclusions}

The study used a secular record of precipitation in Kraków and documented circulation patterns in southern Poland to show patterns in relationships between precipitation types 
and atmospheric circulation at mesoscale. It was found that circulation types, air masses and atmospheric fronts have an influence on the type of precipitation because of seasonal differences in the thermal and moisture properties of air masses. The influence is best demonstrated by circulation types because they take into account not only the cyclonicity/anticyclonicity of inflowing air masses but also their advection sector, two features which control the physical properties of air.

On $43 \%$ of days, weather in southern Poland is determined by four circulation types: $\mathrm{Ka}, \mathrm{Wa}, \mathrm{Wc}$ and $\mathrm{Bc}$. On $58 \%$ of days, the area receives maritime Polar air from the Atlantic whose percentage peaks in summer at $65 \%$. On $40 \%$ of days, the area is swept by atmospheric fronts.

Liquid precipitation, including rain and drizzle, is the most frequent precipitation type in Kraków at $58.1 \%$ of precipitation days in a year. This drops to $31.4 \%$ in winter. The other precipitation types are less frequent, but are strongly varied seasonally. The highest totals, regardless of the type, are recorded in summer, whilst they are not significantly different statistically in spring and autumn. Thunderstorm precipitation with hail is the most productive.

On the basis of the annual average, liquid precipitation is the most frequent in all types of circulation, with the exception of the Ea type during which there is more snow. Depending on the season, three types of circulation, Wa, $\mathrm{Wc}$ or $\mathrm{Bc}$, produce the highest frequency of liquid and thunderstorm precipitation. There is no such dominant type of circulation with mixed precipitation and snowfall as thermal conditions provide an extra variable controlling snowfall in addition to air moisture.

The highest probability of liquid precipitation in summer, more than $50 \%$, was calculated for four different circulation types: Nc, NEc, NWc and Cc. A similarly high probability of winter snowfall was calculated for five circulation types: NEa, Nc, NEc, Ec and Cc. Snowfall in the Ec type also produced the highest totals. Thunderstorm precipitation was the most probable at approx. $35 \%$ in three circulation types - $\mathrm{Bc}, \mathrm{Cc}$ and $\mathrm{Sc}-$ but produced the highest quantities in $\mathrm{Nc}, \mathrm{NEc}, \mathrm{Ec}, \mathrm{Cc}$ and $\mathrm{Bc}$ situations.

High rainfall totals in summer are typical of situations with northern sector advection, i.e. the types Nc and NEc. Assisted by the Carpathian Mountains acting as a physical barrier, these two synoptic situations produce intensive rainfall lasting for several days that have caused some of the largest floods in southern Poland.

The influence of air masses on the occurrence of specific precipitation types is less clear than that of circulation types. In winter, snowfall is the most probable $(50 \%)$ in arctic air, but such air also produces the lowest totals because of the low moisture content in these air masses. In summer, spring and autumn, liquid precipitation is most likely on days with several air masses, a sign of the passage of a front, and in fresh maritime Polar air. The probability of summer thunderstorm precipitation is highest on days when air masses mix (32\%) and in warm air masses: $\mathrm{T}$ (28\%) and $\mathrm{mPw}(24 \%)$.

The probability of precipitation is twice as high in frontal zones as within air masses. For example, in summer, the probability of rainfall without thunder equals $53 \%$ and $24 \%$. Summer thunderstorm precipitation produces the highest daily totals in frontal zones $(10.6 \mathrm{~mm})$ and lower totals when occurring within air masses $(7.9 \mathrm{~mm})$.

Acknowledgements I thank Mr. Paweł. Pilch and Dr. Martin Cahn for reviewing the English. This work was supported by the Polish Ministry of Science and Higher Education under grant no NN306119936.

Open Access This article is distributed under the terms of the Creative Commons Attribution Noncommercial License which permits any noncommercial use, distribution, and reproduction in any medium, provided the original author(s) and source are credited.

\section{References}

Barry RG, Carleton AM (2001) Synoptic and dynamic climatology. Routledge, London

Bergeron T (1928) Über die dredimensional verknüpfende Wetteranalyse. I. Teil [Three-dimensionally combining synoptic analysis. Part I]. Geofysiske Publikasjoner 5:1-111

Bednorz E (2008) Synoptic reasons for heavy snowfalls in the PolishGerman lowlands. Theor Appl Climatol 92:133-140

Bołaszewska J, Reutt F (1962) Częstotliwość występowania poszczególnych mas powietrza w Polsce wokresie 10 lat 1946-1956. Prace PIHM 66:16-32

Cebulak E (1992) Maximum daily precipitation in the upper Vistula Basin. Zeszyty Naukowe Uniwersytetu Jagiellońskiego, Prace Geograficzne 90:79-96 (in Polish with English summary)

Changnon SA (2001) Thunderstorm rainfall in the conterminous United States. Bull Am Meteorol Soc 3:1925-1940

Dai A (2001) Global precipitation and thunderstorm frequencies. Part I: seasonal and interannual variations. J Climate 14:1092-1111

Durkee JD, Frye JD, Fuhrmann CM, Lacke MC, Jeong HG, Mote TL (2007) Effects of the North Atlantic Oscillation on precipitationtype frequency and distribution in the eastern United States. Theor Appl Climatol 94(1-2):51-65

Falarz M (2007) Snow cover variability in Poland in relation to the macro- and mesoscale atmopsheric circulation in the twentieth century. Int J Climatol 27:2069-2081

American Meteorological Society (2000) Glossary of Meteorology. American Meteorological Society, Boston, MA (airmass classification)

Hartley S, Keables MJ (1998) Synoptic associations of winter climate and snowfall variability in New England, USA, 1950-1992. Int J Climatol 18(3):281-298

Hurrell JW (1996) Influence of variations in extratropical wintertime teleconnections on northern hemisphere temperature. Geophys Res Lett 23:665-668

Hurrell JW, Dickson RR (2004) Climate variability over the North Atlantic. In: Stenseth NC, Ottersen G, Hurrell JW, Belgrano A (eds) Marine ecosystems and climate variation-the North Atlantic, vol 36. Oxford University Press, Oxford, pp 301-326 
Kożuchowski K (ed.), (2004) Skala, uwarunkowania i perspektywy współczesnych zmian klimatycznych w Polsce, Zakład Dynamiki Środowiska i Bioklimatologii UŁ, Łódź

Kunkel KE, Angel JR (1999) Relationship of ENSO to snowfall and related cyclone activity in the contiguous United States. J Geophys Res 104:19425-19434

Lamb HH (1972) British Isles weather types and a register of the daily sequence of circulation patterns 1861-1971. Geophysical Memoirs, 16, no. 116, London

McGinnis DL (2000) Synoptic controls on Upper Colorado river basin snowfall. Int J Climatol 20(2):131-149

Niedźwiedź T (1981) Sytuacje synoptyczne i ich wpływ na zróżnicowanie przestrzenne wybranych elementów klimatu w dorzeczu górnej Wisły. Rozprawy habilitacyjne UJ 58:1-165

Niedźwiedź T (2009) Calendar of circulation types, air masses and fronts for Southern Poland. Computer file available at the Department of Climatology, University of Silesia. http://klimat.wnoz.us.edu.pl/

Niedźwiedź T, Twardosz R, Walanus A (2009) Long-term variability of precipitation series in east central Europe in relation to circulation patterns. Theor Appl Climatol 98(3-4):337-350

Przybylak R (2002) Variability of total and solid precipitation in the Canadian Arctic from 1950-1995. Int J Climatol 22:395-420

Spreitzhofer G (1999a) Spatial, temporal and intensity characteristics of heavy snowfall events over Austria. Theor Appl Climatol 62:209-219

Spreitzhofer G (1999b) Synoptic classification of severe snowstorms over Austria. Meteorol Z 8:3-15

Spreitzhofer G (2000) On the characteristics of heavy multiple-day snowfalls in the Eastern Alps. Nat Hazards 21:35-53

Twardosz R (1997) Homogenizacja serii pomiarów opadów atmosferycznych na stacji meteorologicznej w Krakowie. In: Trepińska J (red) Wahania klimatu w Krakowie (1792-1995). Instytut Geografii UJ, Kraków, pp 89-95

Twardosz R (2002-2003) Zmienność opadów śniegu na Pogórzu Wielickim w latach 1971-2000. Folia Geographica, Ser. Geographica Physica 33-34:105-115
Twardosz R (2003a) Long-term snowfall variability in Cracow. Acta Universitatis Wratislaviensis 2542. Prace Geograficzne 75:180 188

Twardosz R (2003b) Origines et évolution des fortes chutes de neige dans le sud de la Pologne (Cracovie, 1863-2000). Publication de l'Association Internationale de Climatologie 15:187-192

Twardosz R (2007) Opady atmosferyczne. In: Matuszko D (red) Klimat Krakowa w XX wieku. Instytut Geografii i Gospodarki Przestrzennej UJ, pp 127-138

Twardosz R (2009) Analysis of hourly precipitation characteristics in Kraków, southern Poland, using a classification of circulation types. Hydrol Res 40(6):553-563

Twardosz R (2010a) An analysis of diurnal variations of heavy hourly precipitation in Kraków using a classification of circulation types over southern Poland. Phys Chem Earth 35:456-461

Twardosz R (2010b) The importance of research into form and type of precipitation in the study of climate change. Rozprawy $i$ Monografie, Acta Agrophysica, (in press).

Twardosz R, Cebulska M (2010) Observations and measurements of precipitation in the Polish province of Galicia in the nineteenth century. In: Przybylak R et al (eds) The Polish climate in the European context: an historical overview. Springer Science+Business Media B. $\mathrm{V}$, Berlin, pp 457-471

Twardosz R, Niedźwiedź T (2001) Influence of synoptic situations on the precipitation in Kraków (Poland). Int $\mathrm{J}$ Climatol 21:467-481

Wibig J (2001) Wpływ cyrkulacji atmosferycznej na rozkład przestrzenny anomalii temperatury i opadów w Europie. Wydawnictwo Uniwersytetu Łódzkiego, Łódź

WMO (World Meteorological Organization) (1998) Manual on codes, 1. WMO Publication, 306, Geneva

Ye $\mathrm{H}$ (2008) Changes in frequency of precipitation types associated with air temperature over Northern Eurasia during 1936-90. J Climate 21:5807-5819

Younkin RJ (1968) Circulation patterns associated with heavy snowfall over the western United States. Mon Weather Rev 96:851-853 